\title{
Nobelprisen i fysiologi eller medisin 2014
}

May-Britt og Edvard I. Moser deler årets nobelpris i fysiologi eller medisin med John O'Keefe, University College London. Det er første gang denne prisen går til Norge. Tildelingen er spesiell også fordi de norske prisvinnerne er uvanlig unge og gift med hverandre. De fikk prisen for sine studier av stedsansen - de undersøkte hvordan rotter kan vite hvor de er og hvor de har vært og hvordan de finner frem i sine omgivelser. Historien startet i London rundt 1970, da O'Keefe viste at celler i hippocampus reagerer selektivt på hvor en rotte befinner seg i et rom. På hvert sted rotta besøker, registreres elektrisk nerveimpulsaktivitet, men én enkelt nervecelle (plasscelle, «place cell») er aktiv bare på ett av disse stedene.

Da May-Britt og Edvard I. Moser startet sin egen forskning i nyopprettede stillinger i Trondheim etter verdifulle læreår og doktorgrad hos Per Oskar Andersen ved Nevrofysiologisk institutt, Universitetet i Oslo, måtte de spørre seg: Hva skal vi satse på? I hippocampus kunne sjansene for store gjennombrudd synes små. Plasscellene var allerede funnet. Hippocampus' betydning for læring og hukommelse, en avgjørende forutsetning for stedsansen, var vel etablert. Men hva med entorhinal cortex, en vanskeligere tilgjengelig og mer komplisert del av hjernebarken med til da nærmest ukjent funksjon? Entorhinalis er målområde for all sensorisk informasjon fra primære sensoriske områder i hjernebarken og nærmest eneste vei til hippocampus med informasjon om tilstanden i og utenfor kroppen.

De kunne neppe ha gjort et bedre valg. Viktige ting måtte skje der, og den som kom dit først med egnede metoder, måtte finne noe.

Ved å sette elektroder i entorhinal cortex på våkne rotter som beveget seg fritt $\mathrm{i}$ et område, fant prisvinnerne enkeltceller som fyrte når rotta ikke bare var på ett sted, men på flere steder i området. På et kart over området dannet stedene et uventet mønster der hvert sted ble hjørne i trekanter som lå inntil hverandre over det hele, slik at de til sammen ble et gitter (gitterceller, «grid cells») (1). Andre celler viste seg snart å reagere på andre signaler: hodets retning (head direction cells), rottas bevegelseshastighet (speed cells), signaler fra vegger og andre hindringer i området (border cells). Informasjonen lagres i nervecellenettverkene gjennom endringer på kontaktstedene mellom dem (synaptisk plastisitet), slik at opprinnelige impulsaktivitetsmønstre kan reproduseres senere. Til sammen representerer mønstrene områder rotta tidligere var $\mathrm{i}$.

Funnene har gjort det mulig å lete etter og finne tilsvarende mekanismer hos mennesker. Vi kan derfor nå (delvis) forklare hvordan vi finner frem i et mørkt rom som vi kjenner fra før. Men det trengs også noen landemerker, for eksempel et nattbord vi tar på, som forankrer kartet vi allerede har i hjernen av det reelle rommet vi befinner oss i. Deretter vil informasjon i form av impulsaktivitet fra perifere sanseorganer fortelle hvordan vi beveger oss i kartet og lose oss gjennom rommet (pathway guidance). Funnene hjelper oss også til å forstå hvordan vi husker gjenstander, fakta, ord og begivenheter (semantisk hukommelse) og kan plassere dette i rom og tid (episodisk hukommelse), ettersom slike mentale prosesser synes å bygge på samme type behandling og til dels samme nettverk som stedsansen (2).

Å ta nye steg er viktig i forskning. Gittercellene ville ikke blitt funnet om ikke rottene hadde fått utforske mye større rom enn det som var vanlig den gang. Man kunne dermed fastslå at primærområdet for stedsansen er entorhinalis. Det var også særlig entorhinalis og ikke hippocampus som var rammet hos den berømte «hukommelsesløse» pasienten HM, ifølge autopsimaterialet.
Noen mener nobelprisen bør tildeles for selve oppdagelsen - oppfølgingen kan andre ta seg av. Komiteen i Stockholm kan ha tatt hensyn til begge aspektene. Det er nærmest utrolig hva prisvinnerne har klart å bygge opp i Trondheim i løpet av få år, fra ingenting til et særdeles aktivt forskningsmiljø med nær 100 ansatte. Satsingen og fremsyntheten fra Norges teknisk-naturvitenskapelige universitet, som gjorde dette mulig, må berømmes. Viktig var det også at de tidlig reiste ut, knyttet nære kontakter med de beste, inklusive O'Keefe, og fikk dem som støttespillere under oppbyggingen i Trondheim. Miljøet tiltrekker seg fremragende forskere fra hele verden. De liker seg. Det skyldes ikke bare forskningen, også det at Moser-paret legger stor vekt på å ta vare på medarbeiderne og får dem til å føle seg hjemme. Forsøksdyrene tas også godt vare på, og de vises gjerne frem til besøkende og i mediene. Slikt bidrar til gode forskningsresultater. Resultatene publiseres jevnlig i topp internasjonale tidsskrifter. Bare siden 2002 har prisvinnerne hatt 31 arbeider i Science, Nature og Nature Neuroscience, foruten et stort antall i andre topptidsskrifter.

Hvordan leder man et så stort forskningsmiljø? Ut fra hva jeg hører, mestrer prisvinnerne også det. De kan umulig delta direkte i alle forsøkene, men de følger med på alt som foregår, planlegger prosjekter, tolker resultater, skriver og styrer det hele. Da oppstår det ikke tvil om hvem som fortjener prisen - laboratoriesjefen eller medarbeidere som gjorde forsøkene - slik man har sett ved noen tidligere nobelprisutdelinger.

Fridtjof Nansen var Norges første nevroforsker. Deretter gikk det mange år før tråden ble tatt opp igjen av Jan B. Jansen og Alf Brodal i Oslo i 1930-årene. De la grunnen til Norges sterke stilling innen nevrovitenskapen. Den skjøt fart fra 1950-årene etter hvert som nye metoder, større ressurser og yngre generasjoner kom til. Inspirert av miljøene de kom fra, ble de selv inspiratorer for nye generasjoner og miljøer. Nobels ærespris i fysiologi eller medisin for 2014 er et strålende resultat av denne utviklingen, som omfatter både grunnforskning og betydelig rekruttering til norsk nevrologi. I dag driver mange grupper i Norge førsteklasses forskning innen nevrovitenskap. Måtte økonomi, politikk og rekruttering sørge for god fortsettelse.

\section{Terje Lømo}

terje.lomo@basalmed.uio.no

Terje Lømo (f. 1935) er professor emeritus ved Institutt for medisinske basalfag, Universitetet i Oslo.

Forfatter har fylt ut ICMJE-skjemaet og oppgir ingen interessekonflikter.

\section{Litteratur}

1. Hafting T, Fyhn M, Molden S et al. Microstructure of a spatial map in the entorhinal cortex. Nature 2005; 436: 801-6.

2. Buzsáki G, Moser El. Memory, navigation and theta rhythm in the hippocampalentorhinal system. Nat Neurosci 2013; 16: 130-8. 